\title{
Hayek and Friedman Live Together in a City: Political Economic Control Fraud as the Method of Governance Demanded by the Logic of Neoliberal Political Economy
}

\author{
Devin T. Rafferty ${ }^{1}$
}

Over the last 30 years, America has witnessed its urban areas transform through the application of neoliberal political economy, going from a state of industrial decay to one of modernized, technologically-advanced, highly skilled service occupations. At the same time, many of this process's socio-economic benefits have largely been concentrated along ethnic lines and rarely bestowed upon original residents, allowing some to rightfully label the movement as gentrification. Thus, we pose the following question: what makes urban electorates consistently vote for administrations that implement economic policies directly antagonistic to their best interests? The answer, we argue, is found in an extension of William K. Black's concept of control fraud, which we label as a 'political economic control fraud'. In doing so, we show how this allows top governing authorities to implement a neoliberal platform of unsustainable policies that, at least initially, causes the economy to grow rapidly, allows them to leverage this and improve their political capital, and enables them to seek higher office and/or private occupations while simultaneously abrogating them of any responsibility associated with the transformation's eventual collapse. Finally, we show that neoliberal political economic governance must necessarily be rooted in fraud since it creates and intensifies a divergence of economic class interests. To overcome this and promote such a platform, politicians appeal to the symbolism Americans attach to freedom and democracy because if the consequences of this ideology were genuinely sold to the electorate their political careers would be short lived. [Article copies available for a fee from The Transformative Studies Institute. E-mail address: journal@transformativestudies.org Website: http://www.transformativestudies.org (C2017 by The Transformative Studies Institute. All rights reserved.]

KEYWORDS: Control Fraud, Neoliberalism, Gentrification, Economic Development, Sustainable Financial Development, Political Economy.

\footnotetext{
${ }^{1}$ Dr. Devin T. Rafferty, Ph.D., is an Assistant Professor of Economics and Finance at Saint Peter's University in Jersey City, NJ. Address correspondence to: Devin T. Rafferty, Saint Peter's University, 2641 John F. Kennedy Blvd, Jersey City, NJ 07306; email: Devin.T.Rafferty@gmail.com.
} 